\title{
Expression, purification and crystallization of wheat profilin (Tri a 12)
}

\author{
Margit Cichna-Markl $1^{*}$, Peter Forstenlechner ${ }^{2}$, Karin Hoffmann-Sommergruber ${ }^{2}$, Dalibor Milić ${ }^{3}$, \\ Dubravka Matković-Čalogovićc ${ }^{3}$, Christina Ecker ${ }^{1}$ \\ From Food Allergy and Anaphylaxis Meeting 2011 \\ Venice, Italy. 17-19 February 2011
}

Wheat profilin, designated Tri a 12, has recently been found to be recognized by specific IgE antibodies in patients suffering from bakers' asthma, wheat induced food allergy and also in patients with grass pollen allergy. Since profilin sequences are highly conserved among plants, individuals who are sensitized to profilin commonly show allergic symptoms to a large number of unrelated plants. Knowledge about the three dimensional structure of these allergenic proteins is necessary to gain information on the surface structure required to predict cross-reactivity. However, in contrast to other plant profilins, the three dimensional structure of Tri a 12 has not been resolved yet.

In the present study Tri a 12 was expressed in E. coli and purified from the soluble fraction by affinity chromatography. The molecular weight and the structural integrity of the recombinant protein were verified by mass spectrometry and circular dichroism, respectively. Recombinant Tri a 12 showed intact secondary structures of mixed alpha helices and beta sheet elements characteristic for members of the profilin protein family. This well characterized batch of purified recombinant wheat profilin was then used for crystallization.

Crystallization conditions were screened with the sitting-drop vapour-diffusion method. The best crystals of wheat profilin with maximal dimensions between 0.1 and $0.3 \mathrm{~mm}$ were observed after one week at $290 \mathrm{~K}$ for reservoir solutions containing 3.2-3.7 mol L-1 sodium formate and $50 \mathrm{mmol} \mathrm{L}-1$ HEPES-NaOH buffer, $\mathrm{pH}=$ 7.5. A data set diffracting to a resolution of $3.3 \AA$ was collected in-house from a single crystal. The crystals belonged to space group P3221, with unit-cell parameters $\mathrm{a}=\mathrm{b}=58.9 \AA, \mathrm{c}=82.5 \AA, \alpha=\beta=90^{\circ}$ and $\gamma=$

University of Vienna, Department of Analytical Chemistry, Vienna, Austria Full list of author information is available at the end of the article $120^{\circ}$. Model building and refinement of the crystal structure, as well as further optimization of crystal diffraction quality is under way.

\section{Acknowledgements}

This work was in part funded by the EC through the EuroPrevall project (FOOD-CT-2005-24 514000), by CEEPUS CII-HU-0010-04-0910 and by the Ministry of Science, Education and Sports of the Republic of Croatia (Grant No. 119-1193079-1084).

\section{Author details}

'University of Vienna, Department of Analytical Chemistry, Vienna, Austria. ${ }^{2}$ Medical University of Vienna, Department of Pathophysiology and Allergy Research, Vienna, Austria. ${ }^{3}$ University of Zagreb, Laboratory of General and Inorganic Chemistry, Zagreb, Croatia.

Published: 12 August 2011

\section{doi:10.1186/2045-7022-1-S1-P4}

Cite this article as: Cichna-Markl et al:: Expression, purification and crystallization of wheat profilin (Tri a 12). Clinical and Translational Allergy 2011 1(Suppl 1):P4.

Submit your next manuscript to BioMed Central and take full advantage of:

- Convenient online submission

- Thorough peer review

- No space constraints or color figure charges

- Immediate publication on acceptance

- Inclusion in PubMed, CAS, Scopus and Google Scholar

- Research which is freely available for redistribution 